\title{
The Unique Study of Talent Cultivation for English Major in Private Universities of China
}

\section{中国民办高校英语专业人才培养的独特性研究}

Received: July 12, 2020

\begin{abstract}
The paper focused on the research of talent cultivation for English major in the universities of China, especially in private universities. It is often criticized that the English major makes no difference from public English or English training. The main problems of English major at present in China Universities are in its personnel cultivating program, and course design. These problems are shown in the paper mainly by case studies, literature research from the authors' teaching experience. To solve these problems, the traditional English major must make some tentative innovation and improvement. For the personnel cultivating, it must make a balance between specialists and generalists. For the major setup, it should make refinement in different fields and aspects to let the students make a choice according to their own interests and characteristics, so the paper proposed the mechanism of general enrollment and stratified cultivating. For the course design, it is necessary to make a change from "learning English" to "learning in English". Learning English mainly lies with students. The learning process, especially the skill-based learning, mainly lies in the learners themselves, while the task of the teacher plays the role of mentor and supervisor. Learning in English is the main direction of English teachers' efforts. It is the main mission of the teachers of English major to teach humanities courses in full English, cultivate students' critical thinking in teaching, and let students actively participate in classroom interaction. With these changes, the English major can strive to achieve its own development by being unique and new.
\end{abstract}

Abstract

Key Words: course design; English major; major setup; personnel cultivating program; private university.
Accepted: September 8, 2020

\author{
Written by: \\ Jia Weizhang ${ }^{38}$ \\ https://orcid.org/0000-0002-5075-2409 \\ Zhang Shufang ${ }^{39}$ \\ https://orcid.org/0000-0002-5531-7633
}

摘要:

本文对我国高校特别是民办高校英语专业人 才培养进行了研究。经常有人批评说, 英语 专业与公共英语或英语培训没有区别。目前 我国高校英语专业存在的主要问题是人才培 养方案和课程设计。本文主要通过个案研究 、文献研究等方法, 结合笔者的教学实践, 对这些问题进行了阐述。要解决这些问题, 传统的英语专业必须在人才培养方案、课程 设计等方面进行尝试性的创新和改进。对于 英语专业人才培养计划来说，必须在“专才” 和“通才”之间取得平衡。在专业设置上，应 在不同的领域和方面进行细化，让学生根据 自己的兴趣和特点进行选择, 因此文章提出 了大类招生、分层培养的机制。在课程设计 上, 有必要从“学英语”转变为“在英语中学” 。“学英语”主要是学生的事。学习过程, 尤 其是技能型学习, 主要在于学习者自身, 而 教师的任务则扮演着指导者和监督者的角色 。“在英语中学”是英语教师努力的主要方向 。用全英语讲授人文学科课程, 在教学中培 养学生的批判性思维, 让学生积极参与课堂 互动, 是英语专业教师的主要任务。借助于 这些变化, 英语专业可以做到人无我有、人 有我新, 从而实现自身的发展。

关键词：课程设计；英语专业；专业设置； 人才培养方案; 民办大学

\footnotetext{
${ }^{38}$ College of English, Zhejiang Yuexiu University, China.

${ }^{39}$ College English Department, Zhejiang Yuexiu University, China.
} 


\section{Introduction}

According to data released on the website of the Ministry of Education, in the structure of private higher education by 2018, there are only 5 institutions providing postgraduate programs. Of the 749 regular institutions of higher education, there are 419 undergraduate universities and 330 vocational colleges (Ministry of Education of the People's Republic of China, 2019). Accordingly, application-oriented education seems to be the best choice for most private universities. However, this conclusion really confuses English major and public English or English training.

The development of English major has been questioned by many scholars and experts in recent years. On November 6, 2018, the APP of Wenhui Daily released an article named "Is the English Major a Conscientious Major?" The article written by a scholar from Fudan University of China directly pointed out that English major had got a serious illness, which immediately provoked an extensive discussion on the development of the English major.

For these problems, the paper argued that the traditional English major must make some tentative innovation and improvement in its program of personnel cultivating, and course design to make it different from public English. These problems are mainly researched in the paper by case studies, literature research from the authors' teaching experience.

\section{Theoretical Framework}

The paper focused on the development of English major in private universities of China. So far as the development of a major is concerned, personnel cultivating program, major setup and course design are inevitable questions.

For the personnel cultivating program of English major, such question as "which matters? a specialist or a generalist?" should be taken into account. Nowadays, the new scientific era is pressed for a versatile person. The paper argued that both liberal arts and liberal science are necessary for the English major.

For the setup of English major, the paper proposed the mechanism of general enrollment and stratified cultivating. General enrollment refers to no major division for students in the first two years. The first two years are focused on the general courses with arts and science in balance. Stratified cultivating refers to the pattern of refinement in different fields and aspects after students enter the stage of major selection. After the two years of the first period, different diversions of English major will be carried out, such as English major, Business English major, Translation major, English Preschool Education major, etc.

For the course design of English major, the paper argued that it is necessary to make a change from "learning English" to "learning in English". "Learning English" mainly lies with students, while "learning in English" is the main direction of English teachers' efforts.

After making these changes in personnel cultivating program, major setup and course design, and with the adaptability of private university itself, the English majors can strive to achieve their own development by being unique and new.

\section{Methodology}

Various methods are employed in the writing of the paper. Of them are mainly: observational method, case study, literature research method, experiential summary method, descriptive approach, induction and deduction.

For observational method, the authors have been English teachers for more than 20 years in China. Especially, from 2014 to 2017, the first author was dean of English department, and participated in the formulation of personnel training program of Zhejiang Yuexiu University of Foreign Languages. The authors have observed the practice of English teaching in China and very clearly known the disadvantages of the current doing in English teaching.

In order to make a further research of the problems, the paper used case study.

In the process of the study, the authors consulted a great deal of literature. These literatures include the former relevant studies; the news on newspapers or on internet, and the literatures on historical events.

The authors' experiences do play a positive role in writing the paper. As mentioned above, as English teachers of universities for more than 20 years in China, the authors have seen through many problems of it. These experiences make them have a further rethought about our teaching and construction on English major, and make them summarize the solutions to these problems. 
In writing the paper, without doubt, descriptive approach is employed in order to describe the real situations happened in the countries.

Lastly, induction and deduction are used to make a deeper research, to make the authors' conclusions about the development of English majors in private universities in China.

\section{Results and Discussion}

\section{Results}

Through the above mentioned methods, the study pointed out the homogenization of English majors in Chinese universities, and proposed some suggestions to the unique development of private universities in China. Exactly, in personnel cultivating program, the paper advocated liberal Arts and Science to balance the general courses; in the setup, the paper proposed the mechanism of general enrollment and stratified cultivating to adapt itself to the employment pressure; in the course design, the paper argued for a change from "learning English" to "learning in English" to improve students' real ability.

\section{Discussions on Talent Cultivation for English Major in Private Universities of China.}

\section{Recent Development of English Major in China.}

On October 15, 2015, an article of People's Daily said:

In recent years, many local universities and colleges are generally feeling the pinch. The campus gets bigger, but it encounters a student crisis. College majors have increased, but the quality of teaching has declined. Professionals say the main reason for this phenomenon is that universities are so keen on "scale" that they ignore "uniqueness". (People’s Daily, 2015).

After the reform and opening up, China's higher education has stepped from the stage of "elite" into the stage of "popular" (Bi Lei, Dou Han \& Zhang Xinru, 2014), and "English fever" once swept across the country. In the mid-1990s, more than 200 universities offered English majors. In 2002, the number increased to 420, and in 2004, the number soared to 598. According to Wang Junju (2015), "Up to now, 994 of the 1,448 undergraduate universities in China offer English majors, with a total number of over 570,000 students". Cai Jigang (2018: 1) pointed out, "In addition to foreign language universities, normal universities and comprehensive universities, most of the featured universities, such as the ones in agriculture, petroleum, marine, medicine, post and telecommunications, and geology, etc. have offered English majors."

On November 6, 2018, Wenhui Daily published an article by Professor Cai Jigang. Professor Cai said in the article:

What is a "no conscience" major? I think there are several standards for it: 1) The training standards of this major are not what the country and society need; 2) The teaching content of this major cannot meet the needs of college students; 3) The reason for the existence of this major is to satisfy the basis for the continuation of the discipline; 4) The reason why this major continues to recruit undergraduate and graduate students regardless of the demand is that these students are the basic conditions for professors to become master and doctoral supervisors. If we use these four characteristics to measure, then we will find that the English major is a veritable "no conscience" major. (Cai Jigang, 2018).

This article, like a tossed stone which raises a thousand ripples, immediately caused the great concern of the personage in the circle. To this end, a special issue of Contemporary Foreign Language Studies (2018 Nov) invites renowned scholars and experts in the field to discuss. In addition, as a think tank research and information platform, YEEWORLD (2019) also launched a column, using the online and offline mode to discuss related issues of English majors, and interviewed 14 big shots to express their opinions.

Cai's article is no doubt a slap in the face for the English major. Although this slap is biased and bigoted, because it is obvious that this article not only fails to solve the problems of English majors, but also takes the edge, completely negating the necessity of the existence of English majors, there is no denying that serious problems have arisen in the English major. The problems of English major are as follows: Where is the specialty of English major? Which is more important: English skills or humanities? How to set up a talent training system for English major? How to improve the English ability of English major? How should the new engineering professional compound talents mentioned in Cai's article be reflected in the training system of English major? And so on. These questions are in urgent need of clear answers from English major. 


\section{Enlightenment of Liberal Arts and Science on English Major.}

Liberal is Latin for "quality of a free man". Ancient Greece advocated liberal education, aiming at cultivating people with broad knowledge and elegant temperament, so that students could shake off vulgarity and awaken excellence. What it achieved was not a specialist without a soul, but a man with a culture. In modern society, liberal education is regarded as a kind of generalist education based on people in the society. It is different from professional education and specialist education. Both humanities and natural science are important components of liberal arts education.

Many scholars (Wu Shiyu, 2013; Zhang Daozheng, 2018; Cha Mingjian, 2018) have mentioned and discussed the importance of liberal Arts education in the English major. However, many universities with English major in China lack the important course of mathematics. The separation of the Arts and the Science has long existed in China's higher education, so curriculum setting is narrow, and students are often fixed on a single professional direction after admission. As a result, the establishment of general courses in universities falls into the confines of Arts and Science. Generally, the courses as history, literature are set in majors of Arts, while the courses as mathematics, computer science are set in majors of Science. Therefore, it is necessary for universities and colleges to break the boundary between different disciplines and advocate students of Arts and Sciences to learn knowledge of the other disciplines selectively and purposefully. Feng Jiagui (2006) argued, "Science and the scientific spirit, as one of the important pillars of the humanistic spirit, together with democracy and the democratic spirit, support the whole foundation of the humanistic spirit."

Mathematics plays a great role in the study of linguistics. When the authors stumbled on Noam Chomsky's transformational generative linguistics theory, it turned out that Chomsky had a background in mathematics. More than that, Gilles Fauconnier of Conceptual Integration Theory had a mathematical background; George Lakoff, the father of cognitive linguistics, also mentioned that abstract mathematical thinking comes from our conceptual metaphor. In China, the most typical example is Professor Feng Zhiwei. Feng Zhiwei is a famous computational linguist in China, specializing in machine translation. Feng Zhiwei was over 80 years old and published more than 10 high-level papers in 2018. The authors respect Professor Feng for his keeping writing and for his abilities tied down to a routine post. In fact, the authors more admire Professor Feng's experience in mathematics as an undergraduate of Arts in Peking University. Professor Feng said in his an article (Zhang Zaiyun, 2017), "As an ordinary linguist, I have deeply felt that science has no division of Arts and Science, and the combination of Arts and Science is the inevitable result of the development of science."

Moreover, mathematics is also a minimalist representation of human abstract thinking, complementing the image thinking of literature and other subjects in Arts. Some comprehensive disciplines developed from natural science, such as system theory, information theory, cybernetics, theory of dissipative structure, synergies, etc. These theories reveal the law of systematic evolution, which is applicable not only in natural systems, but also in social fields. Feng Jiagui (2006) mentioned, "Fuzzy mathematical language is undoubtedly an ideal tool to express human psychological phenomena; the theory of mutation is a mathematical model to grasp the laws of quantitative and qualitative changes in human psychology."

Only by adding mathematics and other natural sciences into the general education curriculum of English majors, can liberal education be truly realized, and the penetration of liberal arts and science will lay a solid foundation for cultivating interdisciplinary talents in the future. The main reason why the English area is not brave enough to move forward, especially toward other science areas, is probably due to the lack of science knowledge. Liu Jiang (2018) pointed out, "It is a valuable exploration to integrate the training of practical or compound talents into the general education system, which avoids the additional burden of cultivating compound talents on higher education outside the general education and professional education."

Therefore, from the perspective of liberal arts and science education, in the basic stage of English major, the addition of mathematics, computer science and other science courses according to the spirit of quality education, is of great significance for the students of English major to adapt themselves to the national conditions, to open their eyes to the whole world, and for the administrators to do well in the construction of English major. 


\section{General Enrollment and Stratified Cultivating.}

With China's needs of economic construction and social development, universities began to expand enrollment, and English major is also going with the flow. However, many universities and colleges make no choice, blindly increase or expand the number of English major, and fail to set the training direction according to the characteristics of the universities and the needs of local economic development. As a result, the phenomenon of homogeneity has emerged, the number of graduates has soared, and the employment of students has been affected.

It is a good choice for English major to carry out the mechanism of general enrollment and stratified cultivating. General enrollment refers to no major division for student in the first two years. Two years later, different diversions of English major will be carried out, such as English major, Business English major, Translation major, English Preschool Education major, etc. The biggest benefit of this approach is that the general education of a major may be consistent in the first two years, and the general education setting permeated by arts and sciences lays a solid foundation for the diversion of any major in the future, and provides students with the widest possible choice of major. At the same time, in the general education stage, the independent selflearning mode, which mainly focuses on the cultivation of language skills, should be implemented, and corresponding management measures such as testing should be followed up in time, so as to pave the way for the improvement of language skills.

Stratified cultivating refers to the pattern of refinement in different fields and aspects after students enter the stage of major selection. Take the authors' university as an example: The university makes three effective integrations of foreign language teaching and professional teaching, theoretical teaching and practical teaching, local education and overseas education. Since the general enrollment and stratified cultivating in 2015, the English major of the university have been subdivided into English Major, Translation Major and Business English Major in the mode of " $2+1+1$ " (two years of general education + one year of professional education + one year of practical education).

In the specific curriculum setting, the professional courses after the diversion should be opened in combination with the actual situation of the whole university. For example, the English major of the authors' university retains the traditional direction of English language and literature, and adds the direction of new media and preschool education. The specialized courses in the direction of new media are mainly taken up by teachers from the College of Communications in the university. Some courses of Business English major are taught by teachers from the International Business College of the university. At the same time, teachers of English major can teach English as a minor subject offered by other colleges. Thus, it realizes the complementary development mode of "English + major" and "Professional + English".

\section{The Connotation Construction of English Major Itself}

The Crisis of English major can be completely settled by keeping pace with the times, that is, from the cultivation of single English language and literature to ESP (English for specific purpose), to the cultivation of inter-disciplinary talent which the country is in short supply, in such fields as the medicine, engineering, agriculture, forestry and artificial intelligence combined with English majors. (Cai Jigang, 2018: 4)

To this, the authors do not agree with completely. The main task of training new engineering talents is in the public English and professional English. However, for English-major students, they cannot study other disciplines excessively, as they must do well in their own major study.

The English major is humanistic in nature (Zeng Yanyu, 2019). Besides high humanistic quality, students majoring in English must have solid English skills, which gives them a huge advantage over non-English majors. This leads to the current problem that has been criticized: English majors do not have their own professional advantages and are not different from public English. This problem just shows that English major must strengthen its own construction and strengthen its humanistic characteristics. Therefore, how to improve the sound English skills of English major and enhance their humanistic quality at same time is an urgent problem to be solved.

The reason why English major is ridiculed as public English or college English is that the classroom teaching of English major is completely reduced to the training of language skills, and the excessive pursuit of various English proficiency tests turns English classes into English training classes. At present, some 


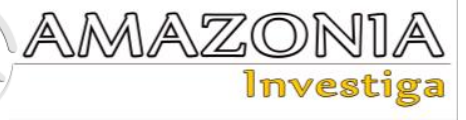

universities of English major try their best to reduce humanities courses, and some even give up humanities courses and literature courses completely. This is a problem for administrators and builders of English majors. Qu Weiguo \& Chen Liufang (2018) pointed out, "In the undergraduate stage, language skills are not the focus of study, and English major should cultivate students' comprehensive academic ability."

As students of English major, they need to show both the excellent English skills and the rich knowledge of humanity. The English major students should have a strong independent learning ability. The authors have deeply realized this point in their undergraduate study: the learning task of English major is far heavier than non-English majors, which requires the students to establish a studious, hard-working learning quality at the very beginning.

However, in the classroom teaching, heavy learning tasks should not be an excuse for teachers to turn English classes into English training classes. So far, in many universities and colleges, such courses as Comprehensive English, English Listening, English Reading and Writing, English Speaking and other skill-based courses are full of the classroom teaching of English major. The existence of these courses crowded out the humanities. The administrators and builders of English major should reflect and correct mistakes in time to let the students of English major turn from "learning English" to "learning in English".

The authors believe that "learning English" mainly lies with students. The learning process, especially the skill-based learning, mainly lies in the learners themselves, while the task of the teachers plays the role of mentor and supervisor. Therefore, to achieve this goal, the computeraided language learning strategies can be used to liberate English teachers from the skill-based curriculum. And "learning in English" is the main direction of English teachers' efforts. It is the main mission of the teachers of English major to teach humanities courses in full English, cultivate students' critical thinking in teaching, and let students actively participate in classroom interaction. Therefore, offering English language and literature courses in an all-round way and increasing relevant humanities courses are the guarantee for the connotation construction of English major.

\section{Conclusions}

1. Computer-assisted Learning and Independent Learning for Students

Computer-assisted Language Learning (CALL) has been around for many years in universities and colleges. At present, with the improvement of running conditions, many schools have invested a lot of financial resources to build independent learning classrooms and made great efforts to introduce various learning software platforms. But the actual effect is not optimistic. At present, these expensive platform devices often become the things that should meet the teaching evaluation standards, and do not really play a role. The main reason for this is the lack of effective management of these hardware platforms, as these facilities are often managed by the technical personnel who do not understand English. Real English teachers do not participate in the management of learning platform, so students' self-study learning becomes ineffective and the assets and equipment are wasteful.

In fact, the effective use of learning platform software or the enhancement of students' selfstudy learning mode is an effective means to liberate the majority of English major teachers from heavy classroom teaching. Foreign countries have already put computer-aided language learning into practice and played a real role. Ai Qing \& Zheng Yongyan (2018) mentioned, "Kyoto University pioneered the introduction of CALL into English courses, and more than 1,000 students have earned credits this way. The subject of autonomous learning is not the teacher, but the students."

In order to improve the efficiency of students' self-study, the effective management of computer-aided teaching should be strengthened. First of all, a large number of courses to improve English skills, such as comprehensive English, listening, speaking, reading and primary writing, should be integrated into the independent learning platform, so that "learning English" becomes students' own business. Secondly, the school should send a small number of English teachers to cooperate with technical personnel to participate in the platform management. The task of teachers is not the traditional classroom teaching mode, but to answer questions of students, to supervise, to manage and other ways. Third, the methods of the assessment of selfstudy learning should be strengthened to avoid the situation of substitute study and false learning of students. The test format can draw experience from the current TOEFL, IELTS and other 
computer-based test format, which can be held regularly, registered independently by students. It is emphasized here that study and examination must be closely combined. Since "learning English" is done by students in an autonomous way, there must be corresponding examination standards. Examination and teaching can be separated, but examination and independent learning must be combined. Only with a strong examination system can the effectiveness of autonomous learning be guaranteed. In this way, students can manage all kinds of English level examination by themselves, and English classroom teaching is no longer any examoriented teaching, to completely separate the teaching and the examination.

\section{Humanities Courses and New Teaching Model}

Once English teachers have been freed from the heavy language skill teaching, there would be plenty of time for the connotation construction of English major.

At present, courses of language skills account for a large proportion in the training programs for English major in many universities and colleges. In the authors' university, for example, among the 160 credits that most English majors must complete, courses of language skills account for more than 40 credits, which is equivalent to nearly half of the credits of the courses of professional education. If these courses can be turned into self-study modes, the design of connotation construction of English major will become more flexible. First, it can provide guarantee for the liberal arts and science education in the lower grades to increase the natural science credits, so that the quality education of free people will no longer become empty words. Second, linguistic courses and literature courses in higher grades can be developed more extensively and deeply, instead of being only introductory forms. For example, in addition to the Introduction to Linguistics, the courses of linguistics can also be Syntax, Pragmatics, Cognitive Linguistics, etc. Literature can be subdivided into English Literature, American Literature, English Poetry Appreciation, English Novel Appreciation and so on. Third, other courses related to English, such as the History of Western Civilization, the History of Western Philosophy, the History of Western Religion, and the History of Western Art, can also be added to broaden the curriculum scope of English major.
The curriculum setting is only one aspect of the connotation construction of English major. In addition, the abolition of skill-based language courses also brings opportunities and challenges to the classroom teaching of English teachers. Without the fetters of examinations, teachers can completely devote themselves to the teaching of English major in class. The teaching mode is no longer a teacher-centered mode with "emphasis on input and ignoring on output", but an outputoriented and student-centered teaching mode. Wang Xia (2018) argued.

In English class, driven by specific problems, by studying several representative works related to the given English text of the subject, we try to solve the problems arising in the text, quickly acquire the subject knowledge while solving doubts, and may naturally master appropriate English language expressions in the process of solving specific problems.

In recent years, there have been many reforms in the mode of classroom teaching. But the premise of teaching mode reform is that the content of teaching should be thoughtful, not just superficial fragmented language materials. It is impossible to carry out productive teaching without critical consciousness and core of critical thinking. Only in a systematic and complete curriculum system can students' critical thinking ability be cultivated. Therefore, the textbooks used by English major should be the classic English textbooks at home and abroad. Some textbooks full of the obvious mistakes at home should be completely abandoned. According to Zhang Wenru (2018), "Let students learn professional background knowledge in a more systematic way, instead of just developing language skills, then the critical thinking training based on this will not be superficial, but flesh and blood."

Of course, both output teaching and studentoriented teaching require teachers to completely change the traditional teaching mode of "one teacher voice". The classroom teaching of English major should be based on interactive discussion, allowing students to question teachers rather than blindly accept their opinions, so as to cultivate students' spirit of challenging authority. Only in this way can students develop their critical thinking. According to Wang Yinquan (2018: 86).

Critical thinking means clearly recognizing and defining problems; distinguishing different arguments and interests on the same issue; collecting relevant materials and analyzing the 


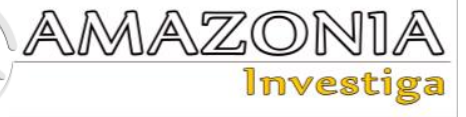

interrelation between different materials; putting forward as many feasible solutions as possible around a problem; analyzing evidence and using inference, analogy and other common reasoning methods to investigate various schemes, and finally putting forward a reasonable judgment and the best scheme.

Therefore, specialized English humanity courses is one of the best ways to cultivate students' thinking habits. It is in the teaching of specialized courses that the best effect of "learning in English" can be achieved.

At the same time, the evaluation method of English major should not adopt the traditional method of finalization examination, but take the output-type, such as the thesis writing of processtype as the main method. Wang Yinquan (2018: 88) pointed out, "In China, the foreign language education in universities has been knowledge teaching so the training of writing at ordinary time were few, the graduate thesis is filled with floods of grammatical errors, or Chinglish. ... the article is too awful to be worth reading."

Therefore, the teaching process of specialized English humanity courses is a process of real reading and writing training, in which students' creative thinking and critical thinking are cultivated.

The key to solve the problems of English major is, according to Li Cuiying (2018), to "eliminate the low quality courses and create an innovative and challenging golden course." As an English major teacher, the content and way of teaching should be completely different from that of a college English teacher or a lecturer in a language training center. Teachers of English major should have high professional academic quality, deep humanistic background and unique academic achievements. Only in this way can they confidently stand on the teaching platform in teaching.

To sum up, the authors have made a tentative discussion on the recent development of English major, the setting of general courses for English major, the layered training mode of English major enrollment and the connotation construction of English major itself. Compared with public institutions, private institutions have their own advantages, such as flexible schoolrunning mechanism, major setting, training plan of talents and so on. All these aspects provide the possibility for cultivating the innovation of English major. Therefore, privately-run universities and colleges should not belittle themselves and reduce their status to cater to the cultivation of so-called "skilled talents". Only by optimizing the curriculum, teaching resources and classroom teaching mode can they move forward steadily.

\section{References}

Ai Qing \& Zheng Yongyan. (2018). The Tradition, Present Situation and Enlightenment of Multilingual Education in Japanese Universities to our Country. Contemporary Foreign Language Studies, 05. 3.

Bi Lei, Dou Han \& Zhang Xinru. (2014). From the "Elite" to "Popular" Quality of Higher Education. The Guide of Science and Education, 05. 3.

Cai Jigang. (2018). The Crisis of English Major and its Way out from the Perspective of National Economic Development Demand. Contemporary Foreign Language Studies, 06. 1, 4.

Cai Jigang. (2018, Nov 6). Is the English Major a Conscientious Major? Wenhui Daily APP, 7.

Cha Mingjian. (2018). The Predicament and Way out of English Major. Contemporary Foreign Language Studies, 06. 11.

Feng Jiagui. (2006). To Strengthen Science Education for Liberal Arts Students. Economic and Social Development, 07. 233.

Li Cuiying. (2018). English Major: Sorry for "Conscience"? Contemporary Foreign Language Studies, 06. 36.

Liu Jiang. (2018). A Multi-perspective Look at the Development Direction of English Major in the New Era. Contemporary Foreign Language Studies, 06. 73.

Ministry of Education of the People's Republic of China (2019, Aug 12). Number of Higher Education Institutions. Retrieved from http://www.moe.gov.cn/s78/A03/moe_560/jytjsj _2018/qg/201908/t20190812_394215.html

People's Daily (2015, Oct 15). How to Solve the Practical Problems of Universities? People's Daily, 12.

Qu Weiguo \& Chen Liufang. (2018). Issues to be Clarified before Treating the Problems of English Major. Contemporary Foreign Language Studies, 06. 17.

Wang Junju. (2015). Conception on National Standard of Curriculum System for Undergraduate English Major. Modern Foreign Languages, 01. 121.

Wang Xia. (2018). A Multi-perspective Look at the Development Direction of English Major in the New Era. Contemporary Foreign Language Studies, 06. 72.

Wang Yinquan. (2018). Strategy of InnovationDriven Development and Countermeasures for 
Cultivating the Innovative Ability of Foreign Language Talents in the New Era. Contemporary Foreign Language Studies, 06, 86, 88.

$\mathrm{Wu}$ Shiyu. (2013). To Explore Various Possibilities of "Destiny" in College English Teaching. China University Teaching, 11. 39.

YEEWORLD. (2019, Dec 4). How to see "no conscience" and "seriously illness" of English Major? Retrieved from https://mp.weixin.qq.com/s/VsNMUgg8oKvXL w4c72MoOw.

Zeng Yanyu. (2019). The Interpretation of The Teaching Guide for Undergraduate English Major. Foreign Language World, 06, 5.
Zhang Daozheng. (2018). To See the "Conscience" of English Major from the "Standard" of Cai Jigang. Contemporary Foreign Language Studies, 06. 34.

Zhang Wenru. (2018). A Multi-perspective Look at the Development Direction of English Major in the New Era. Contemporary Foreign Language Studies, 06. 63.

Zhang Zaiyun (2017, July 13). On the Road of Combining Arts and Sciences: A Record of Mr. Feng Zhiwei, a Natural Language Processing Expert. Sohu.com. Retrieved from https://www.sohu.com/a/156767977_312708. 